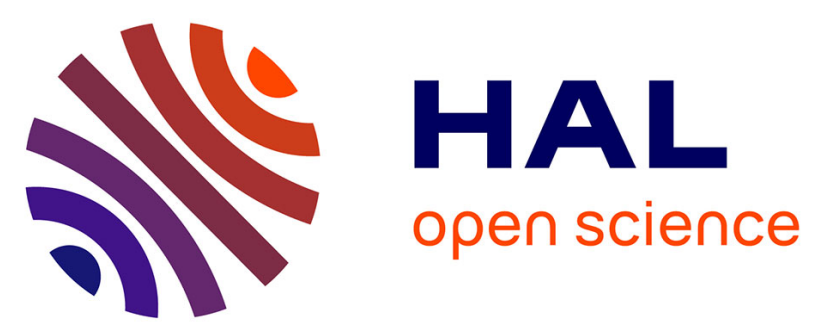

\title{
India and Sunda plates motion and deformation along their boundary in Myanmar determined by GPS
}

Anne Socquet, Christophe Vigny, Nicolas Chamot-Rooke, Wim Simons, Claude Rangin, Boudewijn Ambrosius

\section{- To cite this version:}

Anne Socquet, Christophe Vigny, Nicolas Chamot-Rooke, Wim Simons, Claude Rangin, et al.. India and Sunda plates motion and deformation along their boundary in Myanmar determined by GPS. Journal of Geophysical Research: Solid Earth, 2006, 111 (B5), pp.B05406. 10.1029/2005JB003877 . hal-01793657

\section{HAL Id: hal-01793657 https://hal-ens.archives-ouvertes.fr/hal-01793657}

Submitted on 16 May 2018

HAL is a multi-disciplinary open access archive for the deposit and dissemination of scientific research documents, whether they are published or not. The documents may come from teaching and research institutions in France or abroad, or from public or private research centers.
L'archive ouverte pluridisciplinaire HAL, est destinée au dépôt et à la diffusion de documents scientifiques de niveau recherche, publiés ou non, émanant des établissements d'enseignement et de recherche français ou étrangers, des laboratoires publics ou privés. 


\title{
India and Sunda plates motion and deformation along their boundary in Myanmar determined by GPS
}

\author{
Anne Socquet, ${ }^{1,2}$ Christophe Vigny, ${ }^{1}$ Nicolas Chamot-Rooke, ${ }^{1}$ Wim Simons, ${ }^{3}$ \\ Claude Rangin, ${ }^{4}$ and Boudewijn Ambrosius ${ }^{3}$ \\ Received 8 June 2005; revised 12 January 2006; accepted 15 February 2006; published 6 May 2006.
}

[1] Using a regional GPS data set including 190 stations in Asia, from Nepal to eastern Indonesia and spanning 11 years, we update the present-day relative motion between the Indian and Sundaland plates and discuss the deformation taking place between them in Myanmar. Revisiting measurements acquired on the Main Boundary Thrust in Nepal, it appears that points in southern Nepal exhibit negligible deformation with respect to mainland India. Including these points, using a longer time span than previous studies, and making an accurate geodetic mapping in the newest reference frame allows us to refine the present-day Indian motion. Our results confirm that the current motion of India is slower than predicted by the NUVEL-1A model, and in addition our India-Eurasia motion is significantly $(\sim 5 \mathrm{~mm} / \mathrm{yr})$ slower than previous geodetic determinations. This new Indian motion, combined with a refined determination of the Sundaland motion, gives way to a relative India-Sunda angular velocity of $20.2^{\circ} \mathrm{N}, 26.1^{\circ} \mathrm{E}, 0.370^{\circ} / \mathrm{Myr}$ in ITRF2000, predicting a relative motion of $35 \mathrm{~mm} / \mathrm{yr}$ oriented $\mathrm{N} 10^{\circ}$ at the latitude of Myanmar. There, the Sagaing Fault accommodates only $18 \mathrm{~mm} / \mathrm{yr}$ of right-lateral strike slip, only half of the shear component of motion. We present two models addressing how and where the remaining deformation may occur. A first model of distributed deformation implies convergence on the Arakan subduction (the northern continuation of the now famous Sumatra-Andaman Trench) and wrench faulting in the Arakan wedge. The second model uses localized deformation, where deformation observed west of the Sagaing Fault is entirely due to elastic loading on a faster and oblique Arakan subduction $(23 \mathrm{~mm} / \mathrm{yr})$. This latter model predicts that a major earthquake of $M_{w} 8.5$ may occur every century on this segment of the subduction.

Citation: Socquet, A., C. Vigny, N. Chamot-Rooke, W. Simons, C. Rangin, and B. Ambrosius (2006), India and Sunda plates motion and deformation along their boundary in Myanmar determined by GPS, J. Geophys. Res., 111, B05406, doi:10.1029/2005JB003877.

\section{Introduction}

[2] The India and Sundaland plates abut in Myanmar. Because of sparse geodetic networks in this region of the world, the present-day relative motion between those two plates has remained poorly known. Hence the amount of right-lateral shear and the associated style of active deformation in Myanmar have not been quantified so far. The 26 December 2004 Banda Aceh earthquake and the attendant damages highlighted the urgent need to study active deformation and seismic hazard along adjacent segments of the subduction. The megaearthquake ruptured a $1200-\mathrm{km}-$

\footnotetext{
${ }^{1}$ Laboratoire de Géologie de l'Ecole Normale Supérieure, UMR 8538, Paris, France.

${ }^{2}$ Now at Department of Earth and Space Sciences, University of California, Los Angeles, California, USA.

${ }^{3}$ Department of Earth Observation and Space Systems, Delft University of Technology, Delft, Netherlands.

${ }^{4}$ Collège de France, Chaire de Géodynamique, Europôle de l'Arbois, Aix en Provence, France.

Copyright 2006 by the American Geophysical Union. 0148-0227/06/2005JB003877\$09.00
}

long portion of the trench, starting from the northern edge of the Sumatra Island, and ending offshore from the Andaman Islands, only a few hundred kilometers south of Myanmar shores (Figure 1) [e.g., de Groot-Hedlin, 2005; Ishii et al., 2005; Lay et al., 2005; Lomax, 2005; Vigny et al., 2005]. This earthquake likely increased the stress on adjacent segments of the subduction, raising the seismic hazard at both ends of the rupture. The March $2005 M_{w} 8.7$ Nias earthquake, which occurred just south of the previous rupture, is a case example of the triggered seismicity we can now fear farther north on the Arakan Trench, along the Myanmar-Bangladesh border.

[3] The aim of this paper is to study how the relative India-Sunda motion is accommodated in Myanmar, and in particular the style and rate of deformation along the two main active structures, the Arakan Trench and the Sagaing Fault. We first present our new regional GPS processing and determine the current motion of the Indian Plate with respect to the Sunda Plate. We then focus on the active deformation in Myanmar and discuss the possible distribution of slip along the main faults. Although different models fit our data equally well, we show that a simple locked- 


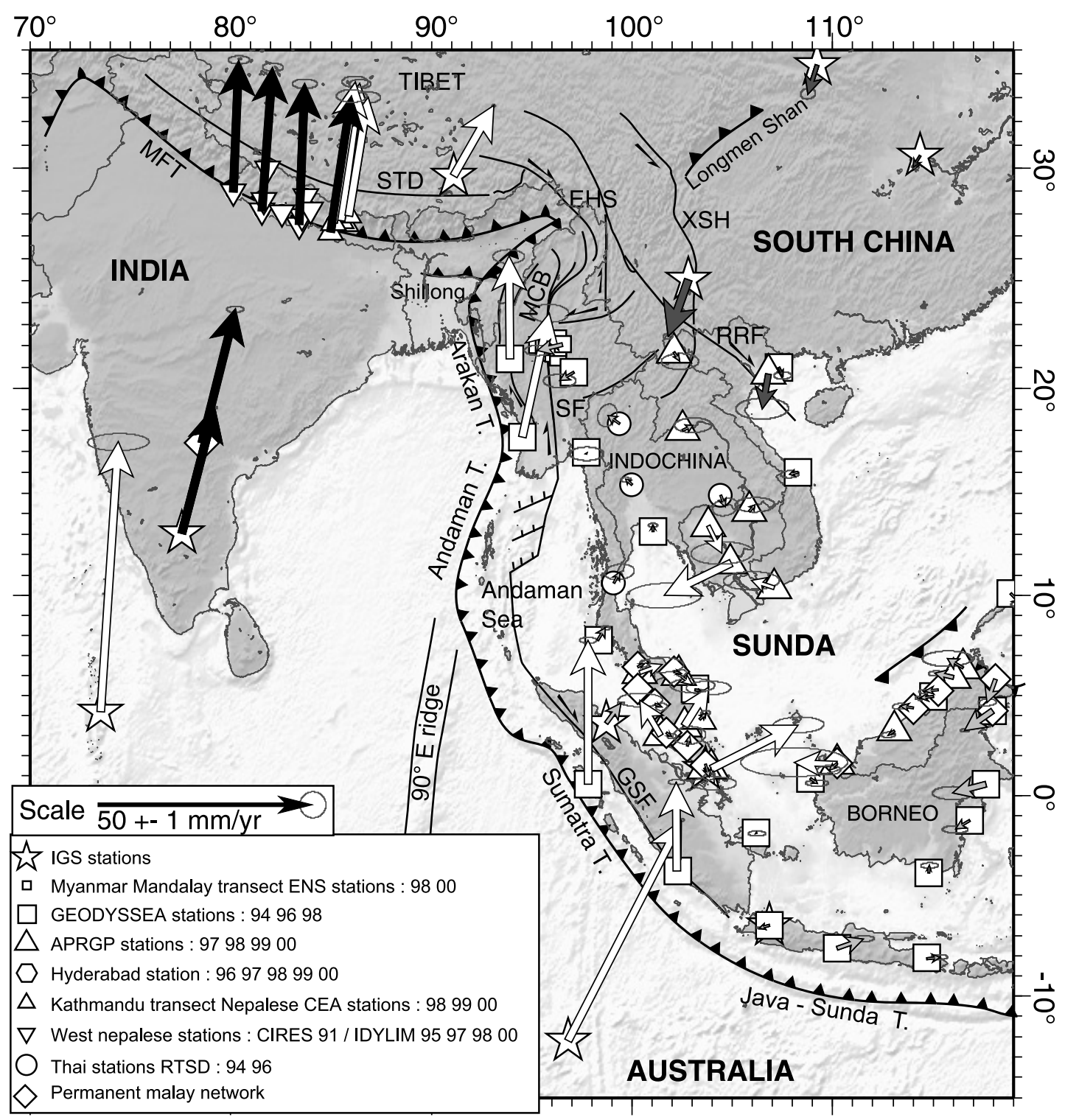

Figure 1. SE Asia GPS velocity vectors with respect to Sunda Plate. Error ellipses show the 99\% confidence level. Black arrows belong to Indian Plate, dark grey arrows belong to south China block, and light grey arrows belong to Sunda. Different symbols indicate data source. The major SE Asian faults and plates are also represented on the GTOPO-30 shaded topography. Abbreviations are as follows: EHS, Eastern Himalayan Syntaxis; GSF, Great Sumatran Fault; MFT, Main Frontal Thrust; MCB, Myanmar Central Basins; SF, Sagaing Fault; RRF, Red River Fault; STD, southern Tibet Detachment; XSH, Xianshuihe Fault.

trench model is plausible and discuss the implications in terms of yearly accumulation of deformation in Myanmar and seismic hazard.

\section{Geodynamic Setting}

[4] Southern Asia is composed of three major plates: the Indian Plate, the Australian Plate, and the Sunda Plate (Figure 1). The Indian Plate extends on the Indian continent and the western part of the Indian Ocean. The Australian Plate extends on the eastern part of the Indian Ocean and the Australian Craton. The Sunda Plate involves the Indochinese and Malaysian peninsulas, the Sunda Shelf, Borneo, Sumatra and Java Islands. Western Indonesia was early recognized as a coherent tectonic entity [Hall, 2002; Hamilton, 1972]. Geodetic measurements confirmed this point and showed that the Sunda Plate is currently moving eastward with respect to the Eurasian Plate [Bock et al., 2003; Chamot-Rooke and Le Pichon, 1999; Michel et al., 2001; Simons et al., 1999].

[5] The triple junction between the Indian, Australian, and Sunda plates is located at the intersection of the Andaman Trench, the Sumatra Trench and the $90^{\circ} \mathrm{E}$ Ridge (Figure 1), where the 26 December 2004 earthquake occurred. The diffuse boundary between the Indian and Australian plates can be approximated by the $90^{\circ} \mathrm{E}$ Ridge. In this area, the oceanic crust consists of three component plates (India, Australia and the Capricorn microplate) and 


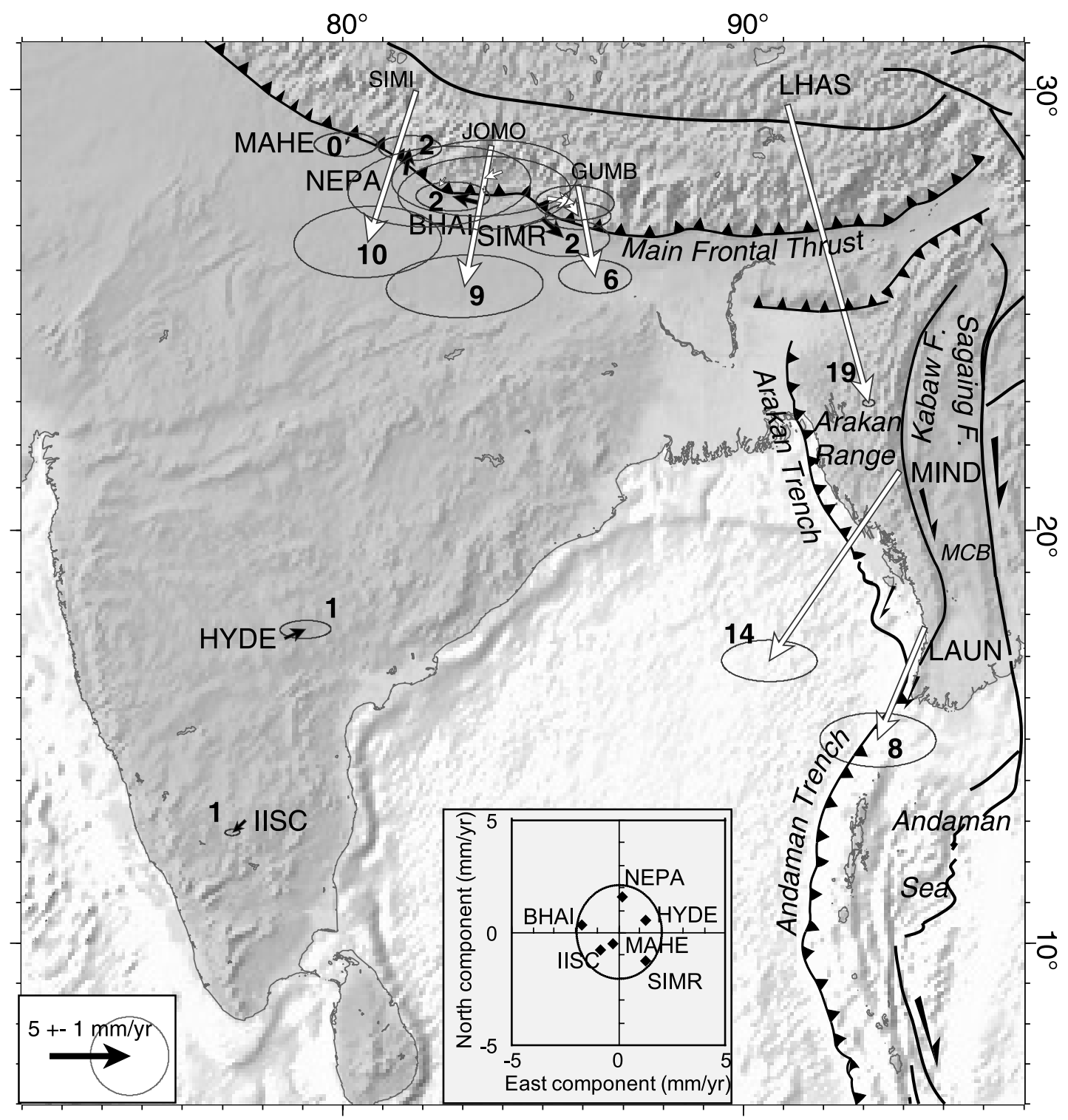

Figure 2. GPS velocities in India, Nepal, and western Myanmar with respect to the Indian Plate. Error ellipses show the 95\% confidence level. Black arrows belong to Indian Plate. The main tectonic structures are also represented on the GTOPO-30 shaded topography. MCB, Myanmar Central Basins. Inset shows vector components of the residual velocities used for the India-ITRF-2000 pole determination. Units are in $\mathrm{mm} / \mathrm{yr}$. Indian stations display residual velocities below $2 \mathrm{~mm} / \mathrm{yr}$ (circle).

multiple diffuse plate boundaries [DeMets et al., 2005; Gordon et al., 1990; Royer and Gordon, 1997]. The boundary between the Indian and Australian plates is a wide region affected by NW-SE compressive deformation of the oceanic lithosphere [Chamot-Rooke et al., 1993] and by active left-lateral strike slip along north trending paleotransform faults [Abercrombie et al., 2003; Deplus, 2001; Deplus et al., 1998]. To the north, the limit between the Indian Plate and the actively deforming Asian continent is the Main Frontal Thrust (Figures 1 and 2) [Cattin and Avouac, 2000; Lavé and Avouac, 2000]. To the east, the Himalayan thrusts connect, in the inner part of the Eastern Himalayan Syntaxis, to the north trending Myanmar structures [e.g., Burg et al., 1998; Holt et al., 1991; Mitchell, 1993; Ratschbacher et al., 1996]. At the latitude of Myan- mar, the Indian Plate slides northward past the Sunda Plate. There, the India-Sunda motion is considered as being partitioned between the $1200-\mathrm{km}$-long right-lateral strikeslip Sagaing Fault and the Andaman-Arakan trenches farther west (Figures 1 and 2) [Le Dain et al., 1984; Michel et al., 2001; Peltzer and Saucier, 1996; Tapponnier and Molnar, 1975; Tapponnier et al., 1982; Curray, 1989; Mitchell, 1993]. South of Myanmar, the Andaman Trench becomes the Sumatra Trench. East of this trench system, the Andaman Basin opens in a pull-apart setting between the Sagaing Fault to the north and the West Andaman and Great Sumatran Fault to the south. The Sumatra Trench runs parallel to the Great Sumatran Fault (Figure 1). Slip partitioning on these two latter Sumatran structures accommodates the oblique Australian-Sunda Plate motion [e.g., 
Table 1. India-South Nepal Stations Baselines Variations

\begin{tabular}{lc}
\multicolumn{1}{c}{ Baseline } & Length Variation, $\mathrm{mm} / \mathrm{yr}$ \\
\hline IISC-HYDE & 2.1 \\
IISC-MAHE & 2.4 \\
IISC-BHAI & 1.9 \\
IISC-NEPA & 1.2 \\
IISC-SIMR & 1.1 \\
HYDE-MAHE & 0.1 \\
HYDE-BHAI & -1.1 \\
HYDE-NEPA & -0.7 \\
HYDE-SIMR & -1.6 \\
\hline
\end{tabular}

Curray, 1989; Fitch, 1972; Genrich et al., 2000; McCaffrey, 1991; McCaffrey et al., 2000; Prawirodirdjo et al., 1997].

[6] In Myanmar, east of the Arakan Trench, the Arakan accretionary wedge is affected by shallow seismicity [Dasgupta et al., 2003; Rao and Kumar, 1999; Satyabala, 2003] along large N/S strike-slip faults [Bender, 1983; Guzman-Speziale and Ni, 1996; Socquet et al., 2002]. The Myanmar Central Basins bound this mountain belt to the east [Bender, 1983; Pivnik et al., 1998; Rangin et al., 1999]. The major tectonic break between the Arakan range and the basins is the Kabaw Fault (or Eastern Boundary Thrust). About $200 \mathrm{~km}$ to the east, the north trending Sagaing Fault cuts through the central basins and follows a zone of topographic gradient, the Shan Scarp, along which the Mogok metamorphic belt outcrops [Bertrand et al., 2001, 1999]. The Sagaing Fault presently ends in a compressional horsetail toward the north in the Himalayan Syntaxis area, and an extensional horsetail toward the south in the Andaman pull-apart (Figure 1) [Curray, 2005; Guzman-Speziale and Ni, 1993; Le Dain et al., 1984].

\section{Data Processing}

[7] The velocity solution presented here is a reprocessing of a mix of campaign and continuous GPS data covering south and southeast Asia. The solution includes $\sim 190$ stations spanning 11 years of data from 1991 to 2002 . We processed new data: the permanent Malaysian network acquisitions from 1999 to 2001, the Asia Pacific Regional Geodetic Project campaigns from 1997 to 2000 [Govind et al., 1999], the first-order Thai network measurements in 1994-1996-2000 and data from Hyderabad GPS station in India from 1996 to 2000, as well as already published data: GEODYSSEA data [Chamot-Rooke and Le Pichon, 1999; Michel et al., 2001; Simons et al., 1999], GPS campaigns in Sulawesi from 1999 to 2002 [Simons et al., 2000; Vigny et al., 2002; Walpersdorf et al., 1998a, 1998b], Myanmar campaigns in 1998 and 2000 [Vigny et al., 2003], west Nepal network measurements in 1991-1995-1997-19982000 [Bilham et al., 1997; Jouanne et al., 1999; Larson et al., 1999], the Kathmandu transect campaigns from 1998 to 2000 [Avouac et al., 2001; Jouanne et al., 2004] and data from 30 IGS stations world wide spread (Figure 1). The raw GPS measurements were analyzed in 24-hour daily solutions with GAMIT [King and Bock, 1999]. Velocities were estimated and mapped in ITRF-2000 [Altamimi et al., 2002] using GLOBK/GLORG software [Herring, 1999]. A slightly different data set $(80 \%$ common stations in SE Asia) was also processed independently with GIPSY OASIS II software [Blewitt et al., 1988] and published separately (W. J. F. Simons et al., A decade of GPS measurements in SE Asia: (Re)defining Sundaland and its boundaries, submitted to Journal of Geophysical Research, 2006). We combined these data with ours, again using GLOBK. The GAMIT processing, the combinations, the reference frame mapping and the error analysis are detailed in the auxiliary material ${ }^{1}$. Figure 1 depicts the velocity field we obtain with respect to the Sunda Plate.

\section{India-Sunda Motion \\ 4.1. India Deformation and Motion}

[8] From a geodetic point of view, the Indian Plate remains undeformed up to the foothills of the Himalaya. Actually, and contrary to what one would expect from simple elastic coupling theories, stations in southern Nepal hardly show any motion with respect to India. Baseline lengths between points located in southern Nepal (MAHE, NEPA, BHAI, and SIMR) and points located farther south in continental India (HYDE and IISC) vary by less than $2 \mathrm{~mm} / \mathrm{yr}$ (Table 1 and Figure 2). Since the residuals do not show any systematic trend, we conclude that these small numbers are representative of the data uncertainties rather than the actual rate of deformation. Larson et al. [1999], Paul et al. [2001], and Jouanne et al. [2004] found similar results since their south Nepalese points move at less than $2 \mathrm{~mm} / \mathrm{yr}$ with respect to IISC. We thus consider in the following that velocities of south Nepal stations are indeed representative of the motion of the Indian Plate. A new geodetic rotation pole for the Indian Plate in ITRF-2000 was thus determined using two Indian stations (IISC and HYDE) and four southern Nepalese stations (MAHE, NEPA, BHAI, SIMR) located south of the Main Frontal Thrust. The Maldives station was not used because we processed only two sets of measurements separated by a year interval only, explaining its poor velocity determination. In any case, Maldives Island is located in the diffuse zone of deformation between India and Australia. In ITRF-2000, our pole determination for the Indian Plate is $50.9^{\circ} \mathrm{N},-12.1^{\circ} \mathrm{E}$, $0.486 \pm 0.01^{\circ} / \mathrm{Myr}$ (Table 2 ). The computed error ellipse was constructed from variance-covariance matrix describing uncertainties, linearly propagated from the errors assigned to the data, following the method described by DeMets et al. [1994]. Its semimajor axis is oriented $\mathrm{N} 108^{\circ}$ and is $5.11^{\circ}$ long and its semiminor axis is $0.61^{\circ}$ long. The shape of the ellipse (ratio between long and short axes and ellipse orientation) is mainly constrained by the geographical distribution of the stations. Here, the longitudinal uncertainty is larger because there is a trade-off between the angular speed and the distance pole/plate. Residual velocities for the stations used for the pole determination are below $2 \mathrm{~mm} / \mathrm{yr}$ with an RMS of $1.29 \mathrm{~mm} / \mathrm{yr}$ (Figure 2).

[9] In order to compare our pole with previous studies, we rotate our India-ITRF-2000 pole with respect to the Eurasian Plate defined by Calais et al. [2003]. With respect to Eurasia, the Indian Plate rotates anticlockwise about a pole located at $27.5^{\circ} \mathrm{N}, 12.9^{\circ} \mathrm{E}$ at a rate of $0.398^{\circ} / \mathrm{Myr}$. Our pole determination predicts a velocity at Bangalore (IISC) of $39 \mathrm{~mm} / \mathrm{yr}$ oriented $\mathrm{N} 25^{\circ}$. This is $20 \%$ slower than the

\footnotetext{
${ }^{1}$ Auxiliary material is available at $\mathrm{ftp}: / / \mathrm{ftp}$.agu.org/apend/jb/ $2005 j b 003877$.
} 
Table 2. Plate Pairs Rotation Parameters Used in This Study

\begin{tabular}{llccc}
\hline & & \multicolumn{3}{c}{ Rotation Parameters } \\
\cline { 3 - 5 } \multicolumn{1}{c}{ Plate Pair } & \multicolumn{1}{c}{ Reference } & 50.9 & Longitude, ${ }^{\circ} \mathrm{E}$ & $\omega,{ }^{\circ} \mathrm{Myr}$ \\
\hline India-ITRF2000 & this study & 27.5 & -12.1 & 0.486 \\
India-Eurasia & this study & 24.4 & 12.9 & 0.398 \\
India-Eurasia & NUVEL-1A & 25.6 & 17.7 & 0.51 \\
India-Eurasia & Paul et al. $[2001]$ & 20.2 & 11.1 & 0.44 \\
India-Sunda & this study & & 26.1 & 0.370 \\
\hline
\end{tabular}

$48 \mathrm{~mm} / \mathrm{yr}$ oriented $\mathrm{N} 21^{\circ}$ predicted by NNR-NUVEL-1A model [DeMets et al., 1990, 1994]. It is also $\sim 5 \mathrm{~mm} / \mathrm{yr}$ slower than the $44 \mathrm{~mm} / \mathrm{yr}$ oriented $\mathrm{N} 22^{\circ}$ at IISC given by the latest previous geodetic study [Paul et al., 2001]. This difference is probably due to the use of a different reference frame for the two GPS solutions (ITRF-2000 versus ITRF96). Also, the technique used by Paul et al. [2001] to map their velocities in ITRF-96 (by applying tight constraints to the coordinates of IISC, KIT3, and POL2) may have forced IISC velocity. Indeed IISC velocity is slower by $2 \mathrm{~mm} / \mathrm{yr}$ northward and faster by $2 \mathrm{~mm} / \mathrm{yr}$ eastward in ITRF-2000 than in ITRF-96. It is quite noticeable that as the determination of the ITRF is refined, the geodetic estimate of the India-Eurasia motion decreases and becomes more oblique.

\subsection{Sunda-India Relative Pole Determination}

[10] To determine the rotation pole between Indian and Sunda plates, we rotate our velocities with respect to the previously defined Indian Plate and minimize, in the least squares sense, the velocities of the stations located on the Sunda Plate. The stations located close to the block boundaries, potentially affected by significant elastic deformation or located in seismically active regions were not selected for the pole determination (eastern margin of Borneo, Java Island, south Sumatran shore). Stations displaying a residual velocity higher than $10 \mathrm{~mm} / \mathrm{yr}$ have been removed too. These nonconsistent velocities are mainly the APRGP stations, most of which have been measured only twice with a year interval, and thus display important uncertainties (Table S4). This leaves us with 33 stations used for the pole determination (PHON, TAUN, OTRI, VIEN, HPAA, NONN, UTHA, SRIS, KHON, CHON in Indochina, BANH, PHUK, ARAU, IPOH, KTPK, GETI, DOP4, SEGA, KUAL, KUAN, UTMJ, NTUS, TANJ in the Malaysian peninsula, TABA, KUCH, BINT, MIRI, BATU, BRUN, LABU, KINA, D005, PUER in Borneo). The relative rotation pole between the Sunda Plate and the Indian Plate is located in North Africa $\left(20.2^{\circ} \mathrm{N}, 26.1^{\circ} \mathrm{E}\right)$ and rotates clockwise at a rate of $0.370^{\circ} / \mathrm{Ma}$. The error ellipse is oriented $\mathrm{N} 158^{\circ}$, with a $2.11^{\circ}$-long semimajor axis and a $0.39^{\circ}$-long semiminor axis as the longitude of the pole is better constrained than the latitude. The residual velocities of Sunda stations with respect to this pole are listed in Table S4. As shown in Figure 3, the residual velocities at stations used for the pole determination are small $(50 \%<$ $2 \mathrm{~mm} / \mathrm{yr}$ ) and have no preferential orientation. Therefore we consider that we reached a robust estimate of the relative India-Sunda motion, more accurate than previous solutions since it includes far more stations over rigid Sunda, and takes into account the slower motion of India, $5 \mathrm{~mm} / \mathrm{yr}$ slower than Paul et al. [2001]. Our new pole predicts a relative India-Sunda motion along the Arakan Trench of 35 $\mathrm{mm} / \mathrm{yr}$ with a $\mathrm{N} 11^{\circ}$ azimuth in central Myanmar $\left(22^{\circ} \mathrm{N}\right)$, and of $36 \mathrm{~mm} / \mathrm{yr}$ with a $14^{\circ}$ azimuth in southern Myanmar $\left(17^{\circ} \mathrm{N}\right)$.

\section{Deformation at the Plate Boundary \\ 5.1. GPS Velocity Field in Myanmar}

[11] Myanmar GPS velocities are shown in Figure 4 in the new Sunda reference frame, together with the active fault traces and the available earthquake focal mechanisms. At the latitude $\sim 22^{\circ} \mathrm{N}$ and east of the Sagaing Fault, YWEN station moves at $6 \mathrm{~mm} / \mathrm{yr}$ with respect to the Sunda Plate. The motion of YWEN is possibly affected by elastic strain loading due to coupling on the Sagaing Fault. The westward component of motion is however best explained by intracontinental deformation at the northern edge of the Indochinese peninsula, due to clockwise rotations evidenced around the Eastern Himalayan Syntaxis [Holt et al., 1991; Ratschbacher et al., 1996; Wang et al., 1998]. This rotational pattern generates shear on the northern edge of the Indochinese peninsula (in Yunnan, China) that is accommodated along E-W left-lateral strike-slip faults [Lacassin et al., 1998; Socquet and Pubellier, 2005; Wang and Burchfiel, 1997; Wang et al., 1998]. East of YWEN, the shallow seismicity of strike-slip type attests that this intracontinental strain probably extends to the Shan Plateau (Figure 4). West

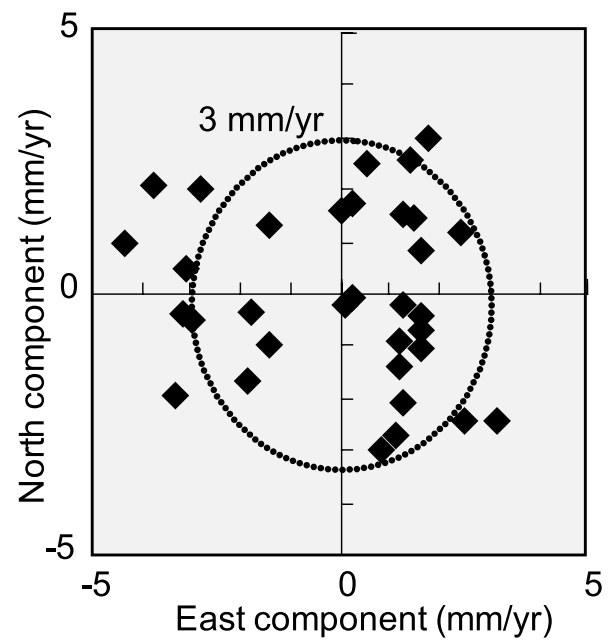

Figure 3. Vector components of the residual velocities used for the India-Sunda pole determination. Units are in $\mathrm{mm} / \mathrm{yr}$. Seventy-three percent of the stations display residual velocities below $3 \mathrm{~mm} / \mathrm{yr}$ (circle), the remaining ones being located close to the plate boundaries. 


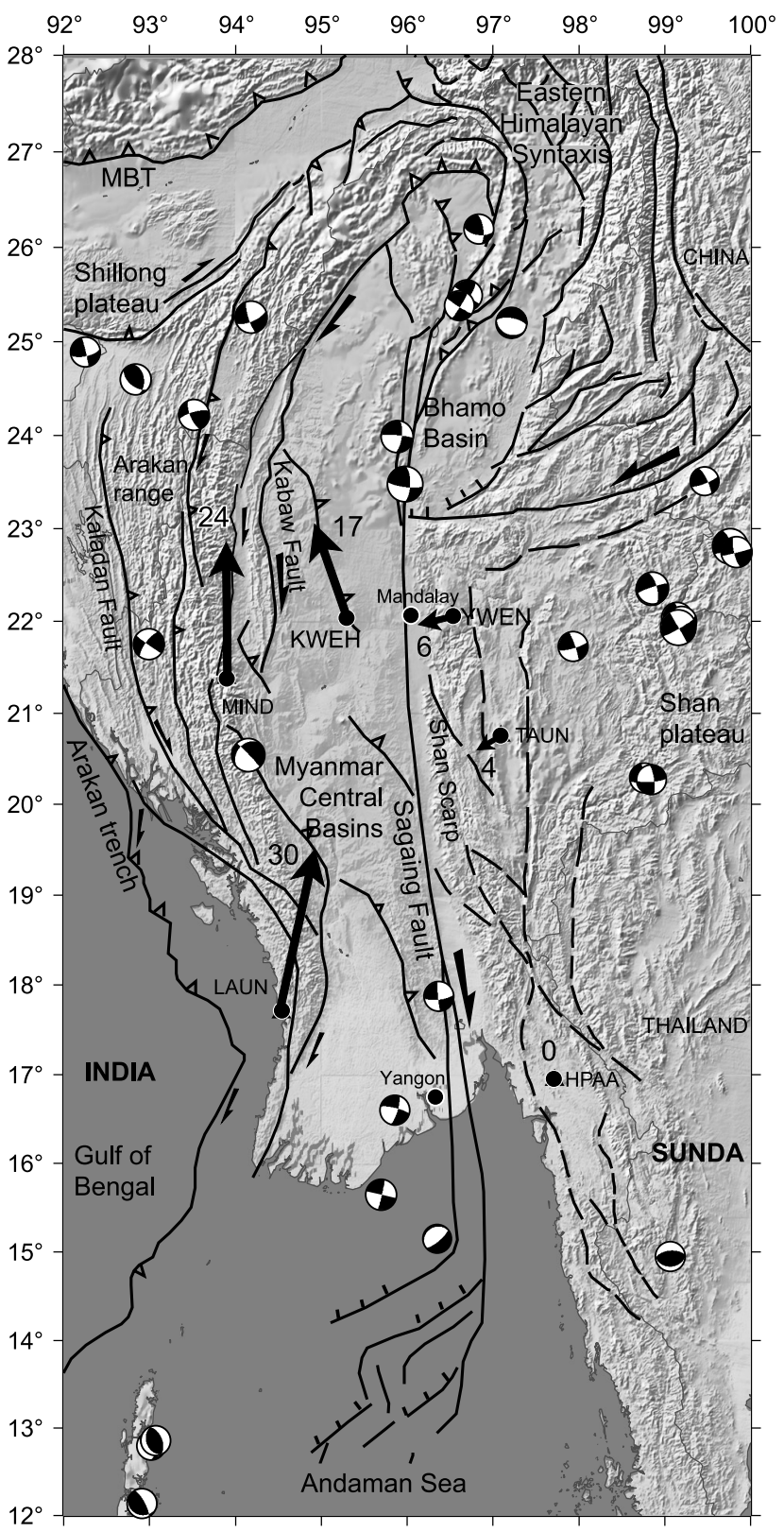

Figure 4. Main Myanmar structures, shallow CMT focal mechanisms, and GPS velocities with respect to the Sunda Plate (black arrows).

of the plateau, the relative motion between KWEH and YWEN indicates that the Sagaing Fault accommodates about $18 \mathrm{~mm} / \mathrm{yr}$ of right-lateral strike slip. This slip amount agrees with the previous geodetic solution [Vigny et al., 2003] and the neotectonic studies [Bertrand et al., 1998]. In the Arakan Range (western Myanmar), MIND station moves $24 \mathrm{~mm} / \mathrm{yr}$ north with respect to Sunda (Figure 4). With respect to India, this station moves $14 \mathrm{~mm} / \mathrm{yr}$ toward the southwest (Figure 2). We summarize in Figure 5 the various GPS constraints in the form of synthetic velocity diagrams. In the velocity vector diagram constructed at this latitude (Figure 5, top), the three heads of the vectors describing the motion of the Indian Plate, KWEH and
MIND sites with respect to the Sunda Plate are aligned. This implies that the motion to be accommodated between the Indian Plate and the Myanmar central basins (KWEH point) has a constant azimuth.

[12] LAUN station is located in southwestern Myanmar south of the Arakan range $\left(17^{\circ} \mathrm{N}\right)$, close to the trace of the Arakan Trench (Figure 4). In this area, offshore data revealed that the trench has a dog-leg shape with strikeslip segments oriented $\mathrm{N} 30^{\circ}$, and thrusts segments oriented $\mathrm{N} 120^{\circ}$ [Nielsen et al., 2004]. In our solution, LAUN moves $8 \mathrm{~mm} / \mathrm{yr}$ to the azimuth $\mathrm{N} 203^{\circ}$ in the Indian reference frame (Figure 2) and up to $30 \mathrm{~mm} / \mathrm{yr}$ with respect to Sunda (Figure 4). Assuming that the estimated slip rate on the central Sagaing Fault can be extrapolated to its southern end, i.e., $18 \mathrm{~mm} / \mathrm{yr}$ oriented $\mathrm{N}-\mathrm{S}$, and further considering that HPAA station belongs to the Sunda Plate (no residual velocity with respect to Sunda), then $20 \mathrm{~mm} / \mathrm{yr}$ oriented $\sim \mathrm{N} 30^{\circ}$ must be accommodated west of the Sagaing Fault (Figure 5, bottom). At this latitude, no major fault exists between the trench and the Sagaing Fault, so that this motion is likely to be accommodated obliquely along the trench itself as suggested by marine surveys [Nielsen et al., 2004].

[13] With respect to Sunda, India moves around $35 \mathrm{~mm} / \mathrm{yr}$ NNE. The Sagaing Fault only accounts for $18 \mathrm{~mm} / \mathrm{yr} \mathrm{N}$. The remaining motion must be taken elsewhere. The question we raise is whether the remaining motion is localized entirely at the trench, as suggested at least for the southernmost segment, or distributed within the Arakan belt. We thus examine quantitatively two models: one where the deformation is distributed onto several faults and one where the motion is localized on two major faults only (the Arakan Trench and the Sagaing Fault, hereafter the two-fault model) with accumulation of interseismic elastic deformation at their locked interfaces.

\subsection{Distribution of the Deformation in Myanmar}

[14] Seismicity and faults mapping in Myanmar support the possibility of distributed deformation. Immediately above the subducted Arakan slab, and possibly within it, both strike-slip and reverse focal mechanisms are observed [Dasgupta et al., 2003; Rao and Kumar, 1999; Satyabala, 2003]. At the surface, the Arakan range is an active foldand-thrust belt, also affected by large N-S strike-slip faults. Shallow seismicity occurs both as strike-slip and thrust events [Guzman-Speziale and Ni, 1996]. Hence both the Arakan Trench and the structures within the Arakan wedge might account for strike-slip and thrust deformation necessary to accommodate the $14 \mathrm{~mm} / \mathrm{yr}$ that occurs between the Indian Plate and MIND station (Figures 4 and 5, top). In this hypothesis, the remaining $9 \mathrm{~mm} / \mathrm{yr}$ oriented $\mathrm{N} 36^{\circ}$ must occur between the Myanmar Central Basin (KWEH) and the Arakan range (MIND) (Figures 4 and 5, top). Directions of the tectonic structures there are mainly N/S [Pivnik et al., 1998; Rangin et al., 1999]. The major fault between the Arakan range and the basins is the Kabaw Fault (also called Eastern Boundary Thrust). Hla Maung [1987] reported transcurrent motion on this fault before the Miocene. If this structure is still active, it would be a good candidate to accommodate part of the right-lateral wrench faulting [Nielsen et al., 2004]. As in the Arakan range, folding is observed within the Neogene sediments of the 

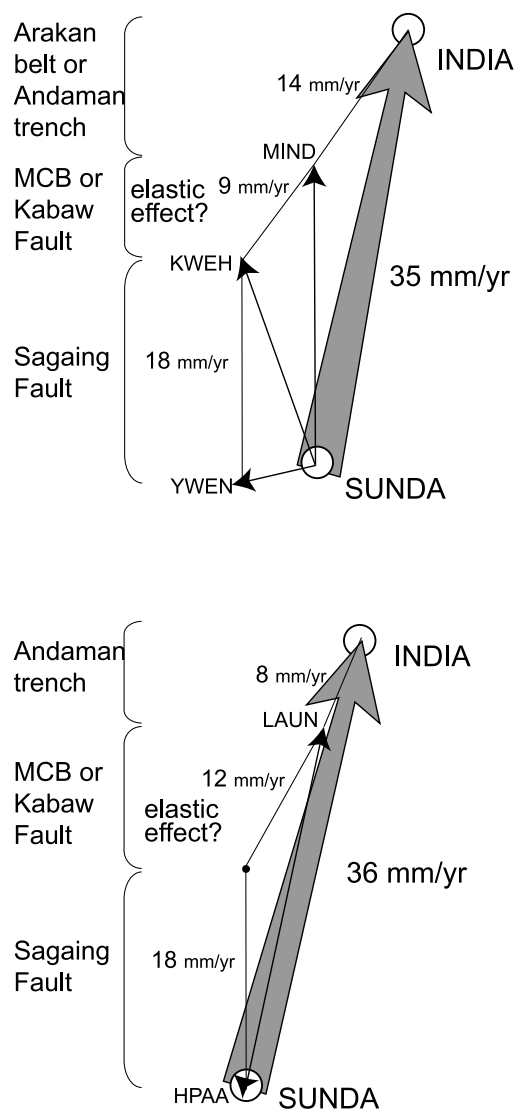

Figure 5. Velocity diagrams showing the distribution of deformation across (top) central and (bottom) southern Myanmar. The plain grey arrows represent India-Sunda motion, small circles represent the plates location in the velocity space, black arrows represent the measured GPS velocities with respect to the Sunda Plate, and the numbers show the amount of motion to be accommodated between the points of the velocity diagram (GPS stations or tectonic plate).

Myanmar Central Basins, although folding is much gentler in the lowlands [Le Dain et al., 1984]. If still actively growing, these en echelon NW-SE folds could also accommodate part of the motion (Figure 4), but it is unlikely that the cumulated motion on them is large. The difficulty in testing more quantitatively the distributed model is that on one hand, it does not rule out the possibility of elastic loading onto a few discrete faults, including the trench itself, and on the other hand, the network we use is clearly not dense enough to recognize narrow high straining zones.

\subsection{Elastic Modeling}

[15] The alternative is to test whether our geodetic solution is compatible with a simple locked-trench and locked-Sagaing Fault model. The rationale is that the observed deformation at our Myanmar GPS stations may be purely transient and related to the combination of interseismic elastic coupling on the Sagaing Fault and the Arakan Trench only. In this case, the Sagaing Fault would be affected by pure strike-slip deformation along its entire length while oblique convergence would be accom- modated on the Arakan subduction from southern Myanmar up to the Shillong Plateau. Although the distribution of GPS sites may be insufficient and constraints on the detailed geometry of the locked subduction interface are obviously lacking, the assumptions are simple enough to perform a first-order test. We constructed a model using DEFNODE software [McCaffrey, 1995, 2002, 2005] considering rigid blocks separated by faults modeled as locked dislocations in an elastic half-space [Okada, 1985]. The two-fault model is schematized in Figure 6. The surface traces of the faults follow the mapping of the Arakan Trench and the Sagaing Fault [Nielsen et al., 2004; Vigny et al., 2003]. The Sagaing Fault is a vertical strike-slip fault locked at $15 \mathrm{~km}$ depth [Vigny et al., 2003]. We consider a dip of $15^{\circ}$ at shallow depths $(<50 \mathrm{~km})$ for the Arakan Trench, constrained by seismicity cross sections [Dasgupta et al., 2003; Satyabala, 2003]. The model is composed of four independent blocks: the Indian and Sunda plates, the Myanmar sliver microplate and the Yunnan block. This last block is a feature used to "mimic" the intracontinental deformation around the Himalayan syntaxis which results in the $6 \mathrm{~mm} / \mathrm{yr}$ westward motion of YWEN in this area. Obviously, this kind of intracontinental distributed strain is difficult to model properly with elastically deforming blocks, but it still needs to be taken into account. This is done by allowing a small westward motion of a block located on the Shan Plateau, and called here the Yunnan Block. While fixing the India-Sunda total motion, we invert the GPS data for the rotation pole of the Myanmar sliver, allowing us to estimate possible rates of slip on the Sagaing Fault and the Arakan Trench. Coherently with Vigny et al. [2003] our best fit model finds that the Sagaing Fault is locked and slips at $18 \mathrm{~mm} / \mathrm{yr}$ (Figure 6, right). Moreover it shows that the velocities at MIND and LAUN (west of the Sagaing Fault) are well explained by elastic loading on the Arakan Trench. The trench would then be locked at $50 \mathrm{~km}$ and would accommodate an oblique slip varying from $20 \mathrm{~mm} / \mathrm{yr}$ oriented $\mathrm{N} 30^{\circ}$ in southern Myanmar (around $17^{\circ}$ of latitude) to $23 \mathrm{~mm} / \mathrm{yr}$ oriented $\sim \mathrm{N} 35^{\circ}$ in central Myanmar (around $22^{\circ}$ of latitude). MIND station is located $\sim 200 \mathrm{~km}$ away from the trench. There, the calculated elastic deformation reaches $5-6 \mathrm{~mm} / \mathrm{yr}$ for the perpendicular component and $7 \mathrm{~mm} / \mathrm{yr}$ for the strike-slip component. Thus elastic loading on the Arakan subduction interface could be responsible for the motion observed at MIND station (Figure 5 (top), MIND to KWEH). Likewise, the motion observed at LAUN station, located at $\sim 50 \mathrm{~km}$ from the trench, can be modeled as the addition of the rigid rotation of the Myanmar sliver and $12 \mathrm{~mm} / \mathrm{yr}$ oriented $\mathrm{N} 30^{\circ}$ of elastic strain due to the loading on the trench (Figure 5 (bottom), LAUN to sliver).

[16] This second hypothesis implies that deformation in Myanmar is partitioned on two main structures: the Sagaing Fault and the Arakan Trench. Such a partitioning mechanism was described previously for the western Sunda Arc where convergence occurs on the Sunda Trench and strike slip on the Great Sumatran Fault [Curray, 1989; Fitch, 1972]. Here, the motion would be partially partitioned with $18 \mathrm{~mm} / \mathrm{yr}$ of pure right-lateral strike slip on the Sagaing Fault and still oblique convergence on the Arakan Trench accommodating about $23 \mathrm{~mm} / \mathrm{yr}$ oriented $\mathrm{N} 35^{\circ}$ 


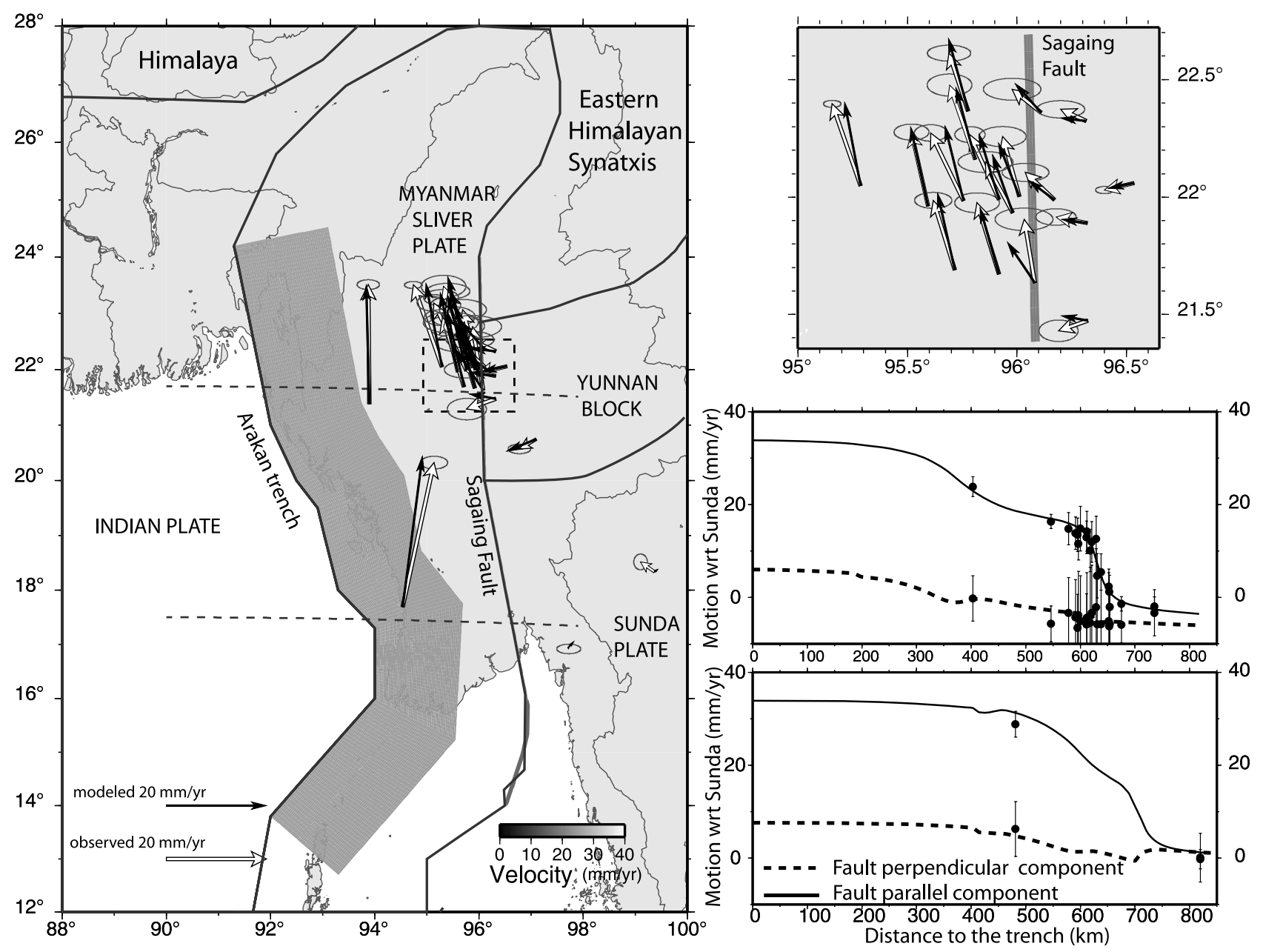

Figure 6. Two-fault (Arakan Trench and Sagaing Fault) elastic loading model of the deformation in Myanmar. The slip on these faults was inverted and its amount is represented with a grey scale. Observed GPS vectors are in white, while the modeled ones are black. The reference frame is the Sunda Block. (left) Regional map showing the geometry and the results of the model. (top right) Detail of the velocities within the Mandalay network, across the Sagaing Fault. (right bottom) E-W cross sections performed at $21.5^{\circ} \mathrm{N}$ (top) and at $17.5^{\circ} \mathrm{N}$ (bottom). They show both the fault normal component (dashed line) and the fault parallel component (solid line) of the velocity. Observed data are represented by dots while the curve depicts the modeled velocity.

( $\sim 18 \mathrm{~mm} / \mathrm{yr}$ of right-lateral strike slip and $\sim 13 \mathrm{~mm} / \mathrm{yr}$ of convergence).

\subsection{Discussion}

[17] While earlier seismologic studies suggested cessation of subduction in Myanmar [Rao and Kumar, 1999], our new data confirm the more recent interpretations of still active subduction [Dasgupta et al., 2003; Satyabala, 2003; Nielsen et al., 2004]. However, the localized versus distributed end-members models remain difficult to discriminate, since structural and geophysical arguments may support each hypothesis. An argument against the distribution hypothesis is that no large straining zone was recognized west of the main Sagaing Fault. Hla Maung [1987] postulates transcurrent motion along the Kabaw Fault, but no geologic nor geophysical evidence was reported to indicate such movement [Khin Zaw, 1990]. Moreover, the folds affecting the Myanmar Central Basins have not accumulated significant shortening since their formation. Pivnik et al.
[1998] interpret the en echelon pattern of the fold axes and reverse faults affecting the basins as the result of internal shear within the sliver, as described by the models of deformation in fore-arc sliver terranes bounded by an oblique subduction zone on one side and a trench-parallel strike-slip fault on the other side [Jarrard, 1986]. Nielsen et al. [2004] proposed partial partitioning onto the Sagaing Fault and the Arakan Trench in southern Myanmar (around $18^{\circ} \mathrm{N}$ ), evolving to full partitioning at higher latitudes (around $25^{\circ} \mathrm{N}$ ); the shear motion taken on the trench would be progressively transferred to several strike-slip and thrust structures within the Arakan wedge. Shallow seismicity north of $20^{\circ} \mathrm{N}$ indeed supports current activity along the strike-slip faults and thrusts affecting the external part of the Arakan wedge, but seems to be restricted to the west of station MIND (Figure 4). If we acknowledge that no significant motion is accommodated between this station and the Sagaing Fault, neither on the Kabaw Fault nor 
within the Myanmar Central Basins, then the measured velocity at MIND station can only be explained by elastic deformation. This pleads for a significant part of the motion being accommodated on the locked subduction plane.

[18] This localized two-fault model yields a high seismic hazard on the Arakan Trench. If we consider a locked plane 400 to $600 \mathrm{~km}$ long and $200 \mathrm{~km}$ wide, which corresponds to a plane locked at $50 \mathrm{~km}$ depth with $15^{\circ}$ dip, with an accumulation of $23 \mathrm{~mm} / \mathrm{yr}$ and a mean crustal shear modulus of $3.3 \times 10^{10} \mathrm{~Pa}$, it would be expected to produce a magnitude 8.5 earthquake every century or a magnitude 9 every 500 years [Kanamori, 1977; Wells and Coppersmith, 1994].

\section{Conclusion}

[19] Our extensive regional GPS velocity field allows us to determine both the relative plate motions and the intracontinental deformation in the region of interaction between India, Eurasia and Sunda plates. Thanks to long time series, numerous measurements in Nepal and the availability of ITRF-2000, our new rotation pole for the Indian Plate yields an India-Eurasia convergence rate significantly slower ( $\sim 5 \mathrm{~mm} / \mathrm{yr})$ than estimated by previous geodetic determination [Paul et al., 2001]. Combined with our refined estimation of Sunda motion, we predict around $36 \mathrm{~mm} / \mathrm{yr}$ of right-lateral N/S strike slip and 7 to $9 \mathrm{~mm} / \mathrm{yr}$ of $\mathrm{E}-\mathrm{W}$ convergence in Myanmar. Distribution of active deformation in Myanmar is constrained by far-field plate motion (India-Sunda motion), near-field GPS measurements (stations in Myanmar), active tectonics on land and at sea (fault styles and rates) and seismological data (focal mechanisms). In southern Myanmar $\left(17^{\circ} \mathrm{N}\right)$, the relative India-Sunda motion is partitioned between the right-lateral Sagaing Fault slipping at $18 \mathrm{~mm} / \mathrm{yr}$ and the Andaman Trench accommodating $20 \mathrm{~mm} / \mathrm{yr}$ of oblique convergence oriented $\mathrm{N} 30^{\circ}$. A similar two-fault partitioning process probably prevails in central Myanmar $\left(22^{\circ} \mathrm{N}\right)$, the shear component west of MIND (about $23 \mathrm{~mm} / \mathrm{yr}$ ) being mainly accommodated as oblique convergence (oriented $\mathrm{N} 35^{\circ}$ ) along the Arakan Trench. A significant portion of the Arakan Trench is thus presently elastically locked and accumulating significant motion. Moreover, this trench portion is localized in a major seismic gap: to the north two $M_{w} 8.7$ earthquakes occurred in 1897 in the Shillong Plateau and in 1950 in Assam, to the south the rupture of the $M_{w} 9.2$ earthquake of December 2004 extended up to the Andaman Islands but not beyond. This has important implications for seismic hazards along the Burma subduction front. The 26 December 2004 earthquake on the Sumatran Trench showed that the northern part of the subduction (Andaman Trench) was locked and had accumulated enough elastic deformation to produce a $M_{w}$ 8.9 earthquake by itself [Vigny et al., 2005]. Our partitioned elastic model with oblique slip on the trench is a simple continuation of this system to the north and yields high probability for one great subduction earthquake of magnitude 8.5 every century in this area.

[20] Acknowledgments. The Myanmar program was initiated in the framework of the GEODYSSEA project between the European commission and the GFZ in Germany. The bulk of the Myanmar campaigns was sponsored by TMEP (GIAC project) and CNRS/INSU contribution. Thanks and appreciations are extended to RTSD for making the THAICA 1994 and
1996 data available, to LDG-CEA, CIRES, and IDYLIM for making the Nepalese data available. We are indebted to Kristine Larson (Department of Aerospace Engineering Sciences, University of Colorado) for providing her reestimated orbits for the 1991 campaign in western Nepal and to François Jouanne (LGCA, Université de Savoie, France) for providing SINEX file for the west Nepal 1995 campaign. Asia Pacific Regional Geodetic Project (APRGP) row GPS data used in this processing were distributed by Geosciences Australia. HYDE station was measured by the National Geophysical Research Institute in Hyderabad (NGRI, India), and data were kindly provided by James Campbell (Geodaetisches Institut der Universitaet Bonn, Germany). We are very grateful to Rob McCaffrey for allowing us to use DEFNODE software he developed at RPI and to R. W. King (MIT) for his generous advice. This paper benefited from very constructive reviews of Paul Tregoning and five anonymous reviewers. The maps in this paper were produced using the public domain Generic Mapping Tools (GMT) software [Wessel and Smith, 1995].

\section{References}

Abercrombie, R. E., M. Antolik, and G. Ekström (2003), The June $2000 M_{w}$ 7.9 earthquakes south of Sumatra: Deformation in the India-Australia Plate, J. Geophys. Res., 108(B1), 2018, doi:10.1029/2001JB000674.

Altamimi, Z., P. Sillard, and C. Boucher (2002), ITRF2000: A new release of the International Terrestrial Reference Frame for earth science applications, J. Geophys. Res., 107(B10), 2214, doi:10.1029/2001JB000561.

Avouac, J. P., et al. (2001), Seismic cycle in the Himalayas, C. R. Acad. Sci., Ser IIa, 333, 513-529.

Bender, F. (1983), Geology of Burma, Borntraeger, Stuttgart, Germany.

Bertrand, G., et al. (1998), The Singu basalts (Myanmar): New constraints for the amount of recent offset on the Sagaing Fault, C. R. Acad. Sci., Ser. IIa, 327, 479-484.

Bertrand, G., C. Rangin, H. Maluski, T. A. Han, M. Thein, O. Myint, W. Maw, and S. Lwin (1999), Cenozoic metamorphism along the Shan scarp (Myanmar): Evidences for ductile shear along the Sagaing fault or the northward migration of the eastern Himalayan syntaxis?, Geophys. Res. Lett., 26, 915-918.

Bertrand, G., et al. (2001), Diachronous cooling along the Mogok Metamorphic Belt (Shan scarp, Myanmar): The trace of the northward migration of the Indian syntaxis, J. Asian Earth Sci., 19, 649-659.

Bilham, R., et al. (1997), GPS measurements of present-day convergence across the Nepal Himalaya, Nature, 386, 61-64.

Blewitt, G., et al. (1988), GPS geodesy with centimeter accuracy, in GPS Techniques Applied to Geodesy and Surveying, Lect. Notes Earth Sci., vol. 19, edited by E. Groten and R. Strauss, pp. 30-40, Springer, New York.

Bock, Y., L. Prawirodirdjo, J. F. Genrich, C. W. Stevens, R. McCaffrey, C. Subarya, S. S. O. Puntodewo, and E. Calais (2003), Crustal motion in Indonesia from Global Positioning System measurements, J. Geophys. Res., 108(B8), 2367, doi:10.1029/2001JB000324.

Burg, J. P., et al. (1998), The Namche Barwa syntaxis: Evidence for exhumation related to compressional crustal folding, J. Asian Earth Sci., 16, $239-252$.

Calais, E., M. Vergnolle, V. San'kov, A. Lukhnev, A. Miroshnitchenko, S. Amarjargal, and J. Déverchère (2003), GPS measurements of crustal deformation in the Baikal-Mongolia area (1994-2002): Implications for current kinematics of Asia, J. Geophys. Res., 108(B10), 2501, doi:10.1029/2002JB002373.

Cattin, R., and J. P. Avouac (2000), Modeling mountain building and the seismic cycle in the Himalaya of Nepal, J. Geophys. Res., 105, 13,38913,408 .

Chamot-Rooke, N., and X. Le Pichon (1999), GPS determined eastward Sundaland motion with respect to Eurasia confirmed by earthquakes slip vectors at Sunda and Philippine trenches, Earth Planet. Sci. Lett., 173, 439-455.

Chamot-Rooke, N., et al. (1993), Intraplate shortening in the central Indian Ocean determined from a $2100-\mathrm{km}$-long north-south deep seismic reflection profile, Geology, 21, 1043-1046.

Curray, J. R. (1989), The Sunda Arc: A model for oblique plate convergence, Neth. J. Sea Res., 24, 131-140.

Curray, J. R. (2005), Tectonics and history of the Andaman Sea region, J. Asian Earth Sci., 25, 187-232.

Dasgupta, S., et al. (2003), The geometry of the Burmese-Andaman subducting lithosphere, J. Seismol., 7, 155-174.

de Groot-Hedlin, C. D. (2005), Estimation of the rupture length and velocity of the Great Sumatra earthquake of Dec 26, 2004 using hydroacoustic signals, Geophys. Res. Lett., 32, L11303, doi:10.1029/2005GL022695.

DeMets, C., et al. (1990), Current plate motions, Geophys. J. Int., 101, $425-478$.

DeMets, C., et al. (1994), Effect of recent revisions to the geomagnetic reversal time scale on estimates of current plate motions, Geophys. Res. Lett., 21, 2191-2194. 
DeMets, C., et al. (2005), Motion between the Indian, Capricorn and Somalian plates since $20 \mathrm{Ma}$ : Implications for the timing and magnitude of distributed lithospheric deformation in the equatorial Indian Ocean, Geophys. J. Int., 161, 445-468.

Deplus, C. (2001), Plate tectonics: Indian Ocean actively deforms, Science, 292, 1850-1851

Deplus, C., et al. (1998), Direct evidence of active deformation in the eastern Indian oceanic plate, Geology, 26, 131-134

Fitch, T. J. (1972), Plate convergence, transcurrent faults, and internal deformation adjacent to Southeast Asia and western Pacific, J. Geophys. Res., 77, 4432-4460

Genrich, J. F., Y. Bock, R. McCaffrey, L. Prawirodirdjo, C. W. Stevens, S. S. O. Puntodewo, C. Subarya, and S. Wdowinski (2000), Distribution of slip at the northern Sumatran fault system, J. Geophys. Res., 105, $28,327-28,342$

Gordon, R. G., C. DeMets, and D. F. Argus (1990), Kinematic constraints on distributed lithospheric deformation in the equatorial Indian Ocean from present motion between the Australian and Indian plates, Tectonics, 9, 409-422.

Govind, R., J. Dawson, D. Sproule, and G. Luton (1999), Combination of high precision space geodetic techniques: The Asia and Pacific Regional Geodetic Project 1997, Adv. Space Res., 23(4), 797-807.

Guzman-Speziale, M., and J. F. Ni (1993), The opening of the Andaman Sea: Where is the short-term displacement being taken up, Geophys. Res. Lett., 20, 2949-2952.

Guzman-Speziale, M., and J. F. Ni (1996), Seismicity and active tectonics of the western Sunda Arc, in The Tectonic Evolution of Asia, edited by A. Yin and T. M. Harrison, pp. 63-84, Cambridge Univ. Press, New York.

Hall, R. (2002), Cenozoic geological and plate tectonic evolution of SE Asia and the SW Pacific: Computer-based reconstructions, model and animations, J. Asian Earth Sci., 20, 353-431.

Hamilton, W. B. (1972), Plate tectonics of Southeast Asia and Indonesia, Am. Assoc. Pet. Geol. Bull., 56, 621.

Herring, T. A. (1999), Documentation for the GLOBK software version 5.01, Mass. Inst. of Technol., Cambridge.

Hla Maung (1987), Transcurrent movements in the Burma-Andaman Sea region, Geology, 15, 911-912.

Holt, W. E., et al. (1991), The active tectonics of the eastern Himalayan syntaxis and surrounding regions, J. Geophys. Res., 96, 14,595-14,632.

Ishii, M., et al. (2005), Extent, duration and speed of the 2004 SumatraAndaman earthquake imaged by the Hi-Net array, Nature, 435, $1127-$ 1133 .

Jarrard, R. (1986), Terrane motion by strike-slip faulting of fore-arc systems, Geology, 14, 780-783.

Jouanne, F., J. L. Mugnier, M. R. Pandey, J. F. Gamond, P. Le Fort, L. Serrurier, C. Vigny, and J. P. Avouac (1999), Oblique convergence in the Himalayas of western Nepal deduced from preliminary results of GPS measurements, Geophys. Res. Lett., 26, 1933-1936.

Jouanne, F., et al. (2004), Current shortening across the Himalayas of Nepal, Geophys. J. Int., 157, 1-14.

Kanamori, H. (1977), Energy release in great earthquakes, J. Geophys. Res., 82, 2981-2987.

Khin Zaw (1990), Geological, petrological and geochemical characteristics of granitoid rocks in Burma: With special reference to the associated W-Sn mineralization and their tectonic setting, J. Southeast Asian Earth Sci., 4, 293-335.

King, R. W., and Y. Bock (1999), Documentation for the GAMIT GPS software analysis version 9.9, Mass. Inst. of Technol., Cambridge.

Lacassin, R., et al. (1998), Hairpin river loops and slip-sense inversion on Southeast Asian strike-slip faults, Geology, 26, 703-706.

Larson, K. M., R. Bürgmann, R. Bilham, and J. T. Freymueller (1999), Kinematics of the India-Eurasia collision zone from GPS measurements, J. Geophys. Res., 104, 1077-1094.

Lavé, J., and J. P. Avouac (2000), Active folding of fluvial terraces across the Siwaliks Hills, Himalayas of central Nepal, J. Geophys. Res., 105 , $5735-5770$

Lay, T., et al. (2005), The great Sumatra-Andaman earthquake of 26 December 2004, Science, 308, 1127-1133.

Le Dain, A. Y., P. Tapponnier, and P. Molnar (1984), Active faulting and tectonics of Burma and surrounding regions, J. Geophys. Res., 89, 453472.

Lomax, A. (2005), Rapid estimation of rupture extent for large earthquakes: Application to the 2004, M9 Sumatra-Andaman mega-thrust, Geophys. Res. Lett., 32, L10314, doi:10.1029/2005GL022437.

McCaffrey, R. (1991), Slip vectors and stretching of the Sumatran Fore Arc, Geology, 19, 881-884.

McCaffrey, R. (1995), DEFNODE users' guide, Rensselaer Polytech. Inst., Troy, N. Y. (Available at http://www.rpi.edu/ mccafr/defnode)

McCaffrey, R. (2002), Crustal block rotations and plate coupling, in Plate Boundary Zones, Geodyn. Ser., vol. 30, edited by Seth Stein and Jeffrey
T. Freymueller, pp. 101-122, doi:10/1029/030GD06, AGU, Washington, D. C.

McCaffrey, R. (2005), Block kinematics of the Pacific-North America plate boundary in the southwestern United States from inversion of GPS, seismological, and geologic data, J. Geophys. Res., 110, B07401, doi:10.1029/2004JB003307.

McCaffrey, R., P. C. Zwick, Y. Bock, L. Prawirodirdjo, J. F. Genrich, C. W. Stevens, S. S. O. Puntodewo, and C. Subarya (2000), Strain partitioning during oblique plate convergence in northern Sumatra: Geodetic and seismologic constraints and numerical modeling, J. Geophys. Res., 105, $28,363-28,376$

Michel, G. W., et al. (2001), Crustal motion and block behaviour in SEAsia from GPS measurements, Earth Planet. Sci. Lett., 187, 239-244.

Mitchell, A. H. G. (1993), Cretaceous-Cenozoic tectonic events in the western Myanmar (Burma) Assam region, J. Geol. Soc., 150, 10891102

Nielsen, C., et al. (2004), From partial to full strain partitioning along the Indo-Burmese hyper-oblique subduction, Mar. Geol., 209, 303-327.

Okada, Y. (1985), Surface deformation due to shear and tensile faults in a half-space, Bull. Seismol. Soc. Am., 75, 1135-1154.

Paul, J., et al. (2001), The motion and active deformation of India, Geophys. Res. Lett., 28, 647-650.

Peltzer, G., and F. Saucier (1996), Present-day kinematics of Asia derived from geologic fault rates, J. Geophys. Res., 101, 27,943-27,956.

Pivnik, D. A., et al. (1998), Polyphase deformation in a fore-arc/back-arc basin, Salin subbasin, Myanmar (Burma), AAPG Bull., 82, 1837-1856.

Prawirodirdjo, L., Y. Bock, R. McCaffrey, J. Genrich, E. Calais, C. Stevens, S. S. O. Puntodewo, C. Subarya, J. Rais, and P. Zwick (1997), Geodetic observations of interseismic strain segmentation at the Sumatra subduction zone, Geophys. Res. Lett., 24, 2601-2604.

Rangin, C., et al. (1999), Cenozoic pull-apart basins in central Myanmar; the trace of the path of India along the western margin of Sundaland, paper presented at European Union of Geosciences conference, EUG 10 , Strasbourg, France, 28 March to 1 April.

Rao, N. P., and M. R. Kumar (1999), Evidences for cessation of Indian plate subduction in the Burmese arc region, Geophys. Res. Lett., 26, 31493152 .

Ratschbacher, L., et al. (1996), Cenozoic deformation, rotation and stress patterns in eastern Tibet and western Sichuan, China, in The Tectonic Evolution of Asia, edited by A. Yin and T. M. Harrison, pp. 227-249, Cambridge Univ. Press, New York.

Royer, J. Y., and R. Gordon (1997), The motion and boundary between the Capricorn and Australian plates, Science, 277, 1268-1274.

Satyabala, S. (2003), Oblique plate convergence in the Indo-Burma (Myanmar) subduction region, Pure Appl. Geophys., 160, 1611-1650.

Simons, W. J. F., et al. (1999), Observing plate motions in Southeast Asia:; Geodetic results of the GEODYSSEA Project, Geophys. Res. Lett., 26 2081-2084

Simons, W. J. F., et al. (2000), Geodynamics of S. E. Asia; first results of the Sulawesi 1998 GPS campaign, IAG Gen. Assembly, 121, 271-277.

Socquet, A., and M. Pubellier (2005), Cenozoic deformation in western Yunnan (China-Myanmar border), J. Asian Earth Sci., 24, 495-515.

Socquet, A., et al. (2002), Late Cretaceous to Eocene metamorphism of the internal zone of the Indo-Burma range (western Myanmar): Geodynamic implications, C. R. Geosci., 334, 573-580.

Tapponnier, P., and P. Molnar (1975), Major strike-slip faulting in China: Its significance for Asian tectonics, Seismol. Soc. Am. Annu. Meet., 7, 425426.

Tapponnier, R., et al. (1982), Propagating extrusion tectonics in Asia; new insights from simple experiments with plasticine, Geology, 10, 611-616.

Vigny, C., et al. (2002), Migration of seismicity and earthquake interactions monitored by GPS in SE Asia triple junction: Sulawesi, Indonesia, J. Geophys. Res., 107(B10), 2231, doi:10.1029/2001JB000377.

Vigny, C., A. Socquet, C. Rangin, N. Chamot-Rooke, M. Pubellier, M. Bouin, G. Bertrand, and M. Becker (2003), Present-day crustal deformation around Sagaing fault, Myanmar, J. Geophys. Res., 108(B11), 2533, doi:10.1029/2002JB001999.

Vigny, C., et al. (2005), GPS unveils actual impact of the mega thrust earthquake in SE Asia, Nature, 24, 495-515.

Walpersdorf, A., et al. (1998a), GPS compared to long-term geologic motion of the north arm of Sulawesi, Earth Planet. Sci. Lett., 159 $47-55$.

Walpersdorf, A., et al. (1998b), Determining the Sula block kinematics in the triple junction area in Indonesia by GPS, Geophys. J. Int., 135, 351-361.

Wang, E., and B. C. Burchfiel (1997), Interpretation of Cenozoic tectonics in the right-lateral accommodation zone between the Ailao Shan shear zone and the eastern Himalayan syntaxis, Int. Geol. Rev., 39, 191-219.

Wang, E., et al. (1998), Late Cenozoic Xianshuihe-Xiaojiang, Red River, and Dali fault systems of southwestern Sichuan and central Yunnan, China, Spec. Pap. Geol. Soc. Am., 327, 108 pp. 
Wells, D. L., and K. J. Coppersmith (1994), New empirical relationships among magnitude, rupture length, rupture width, rupture area, and surface displacement, Bull. Seismol. Soc. Am., 84, 974-1002.

Wessel, P., and W. H. F. Smith (1995), New version of the generic mapping tools released, Eos Trans. AGU, 76(33), 329.

B. Ambrosius and W. Simons, Department of Earth Observation and Space Systems, Delft University of Technology, Kluyverweg 1, Delft, NL2629 HS, Netherlands.
N. Chamot-Rooke and C. Vigny, Laboratoire de Géologie de l'Ecole Normale Supérieure, UMR 8538, 24 Rue Lhomond, F-75231 Paris, France. C. Rangin, Collège de France, Chaire de Géodynamique, Europôle de 1'Arbois, BP 80, G-13545 Aix en Provence Cedex 04, France.

A. Socquet, Department of Earth and Space Sciences, University of California, Los Angeles, 595 Charles E. Young Drive East, Los Angeles, CA 90095-0000, USA. (socquet@ucla.edu) 